\title{
A COMPARISON OF THE EFFECTS OF THIOPENTONE AND HALOTHANE ANAESTHESIA ON CRITICAL OXYGEN TENSION
}

\author{
B. MACLEOD ${ }^{*}$
}

RECENT wORK has shown that barbiturate anaesthesia protects tissues against hypoxic damage. ${ }^{1,2}$ The mechanism by which this occurs is unknown. ${ }^{3}$ However, it is known that barbiturates as well as halothane affect the respiratory enzymes. ${ }^{4-9}$ This information has been obtained from tissue culture. Unfortunately it is difficult to extrapolate results from tissue culture to whole animals. It is also difficult to extrapolate to clinically comparable concentrations of anaesthetic agents. ${ }^{10}$

We have therefore used changes in the critical oxygen tension to compare anaesthetic effects on respiratory enzymes in the whole animal at clinical anaesthetic concentrations. The critical oxygen tension is that oxygen tension at which the respiratory enzymes are first affected by a lack of oxygen. This point was determined from a plot of oxygen tension versus time. Above the critical oxygen tension, oxygen consumption is high and fixed. Below the critical oxygen tension, the oxygen consumption decreases as the oxygen tension decreases. This critical oxygen tension has been determined previously for many tissues including brain, heart and kidney. However, the effect of various anaesthetic agents on critical oxygen tension has not been determined.

\section{METHOD}

Experiments were performed on male New Zealand white rabbits whose weight averaged $2.5 \mathrm{~kg}$. After induction of anaesthesia the trachea was cannulated. Five per cent dextrose in saline was given at the rate of $10 \mathrm{ml} / \mathrm{hr}$ through a cannula in a femoral vein. Cannulation of a femoral artery allowed continuous blood pressure recording and blood gas sampling. Rectal temperature was maintained at $37^{\circ} \mathrm{C}$ by use of a thermostatically controlled heating blanket.

The left kidney was exposed by a midline abdominal incision. A ligature, which could be tightened to produce intermittent arterial occlusion, was placed about the renal artery. The renal capsule was removed. A $15 \mu$ platinum membrane covered oxygen electrode (Radiometer E 5046) was rested against the renal cortex. The signal was amplified by a Radiometer PHA 930 and recorded on a Rikadenki \#B107 10-inch strip chart recorder (Figure 1).

A Dräger vaporizer was used to administer halothane. The rabbits breathed spontaneously through an Ayre's T-piece. Blood gases were determined on a Radiometer PHM 71. A 2.5\% solution of thiopentone was used. The anaesthetic

B. MacLeod, M.D., F.R.C.P.(C), The Departments of Anaesthesia and Pharmacology, The University of British Columbia, Vancouver, B.C., Canada, V6T 1W5.

${ }^{\circ}$ Supported by a Medical Research Council of Canada Fellowship. 


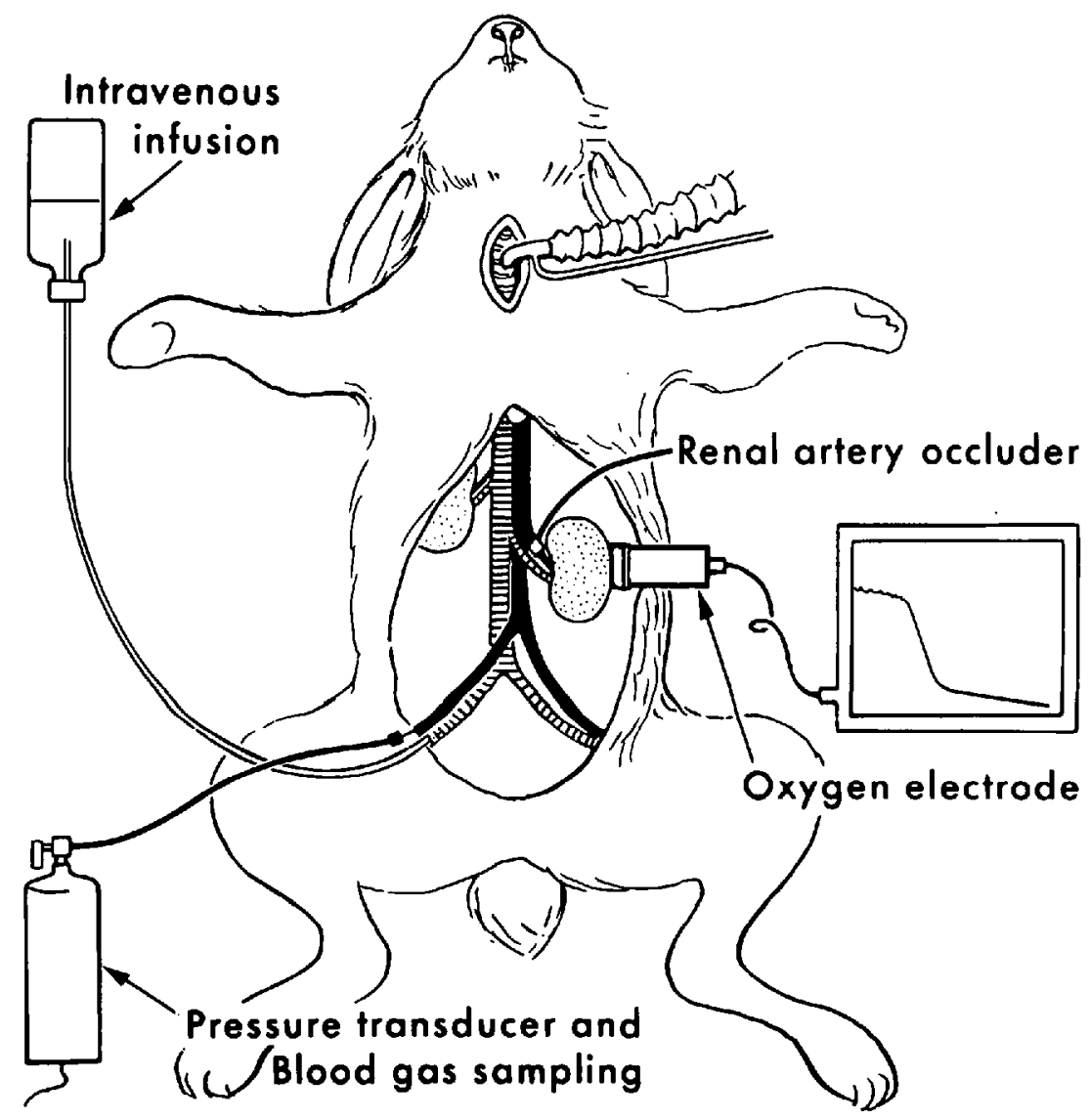

Ficure 1

agents were given at such a rate as to obtund the response to tail squeeze. The inspired halothane concentration ranged from 0.7 to 1 percent. Thiopentone varied from 0.5 to $0.7 \mathrm{mg} / \mathrm{kg} / \mathrm{min}$.

Critical oxygen tension was determined from the recorded trace after arterial occlusion. The tension at which oxygen consumption is reduced to one-half the initial oxygen consumption is the critical oxygen tension (Figure 2). Three readings were taken for each of the agents during an experiment.

Two groups of five rabbits each were utilized.

Group I underwent an inhalational induction with halothane by mask. After one hour at standard anaesthetic depth (the lowest concentration which prevents movement in response to a tail squeeze), three readings of critical oxygen were obtained. Blood pressure and resting surface oxygen recordings were held within 10 per cent of the original. One hour after discontinuance of halothane, during which time anaesthesia was maintained with intermittent thiopentone, three more readings were obtained.

Group II had the sequence reversed, with thiopentone induction and halothane after one hour. Three readings were taken with each anaesthetic agent. 


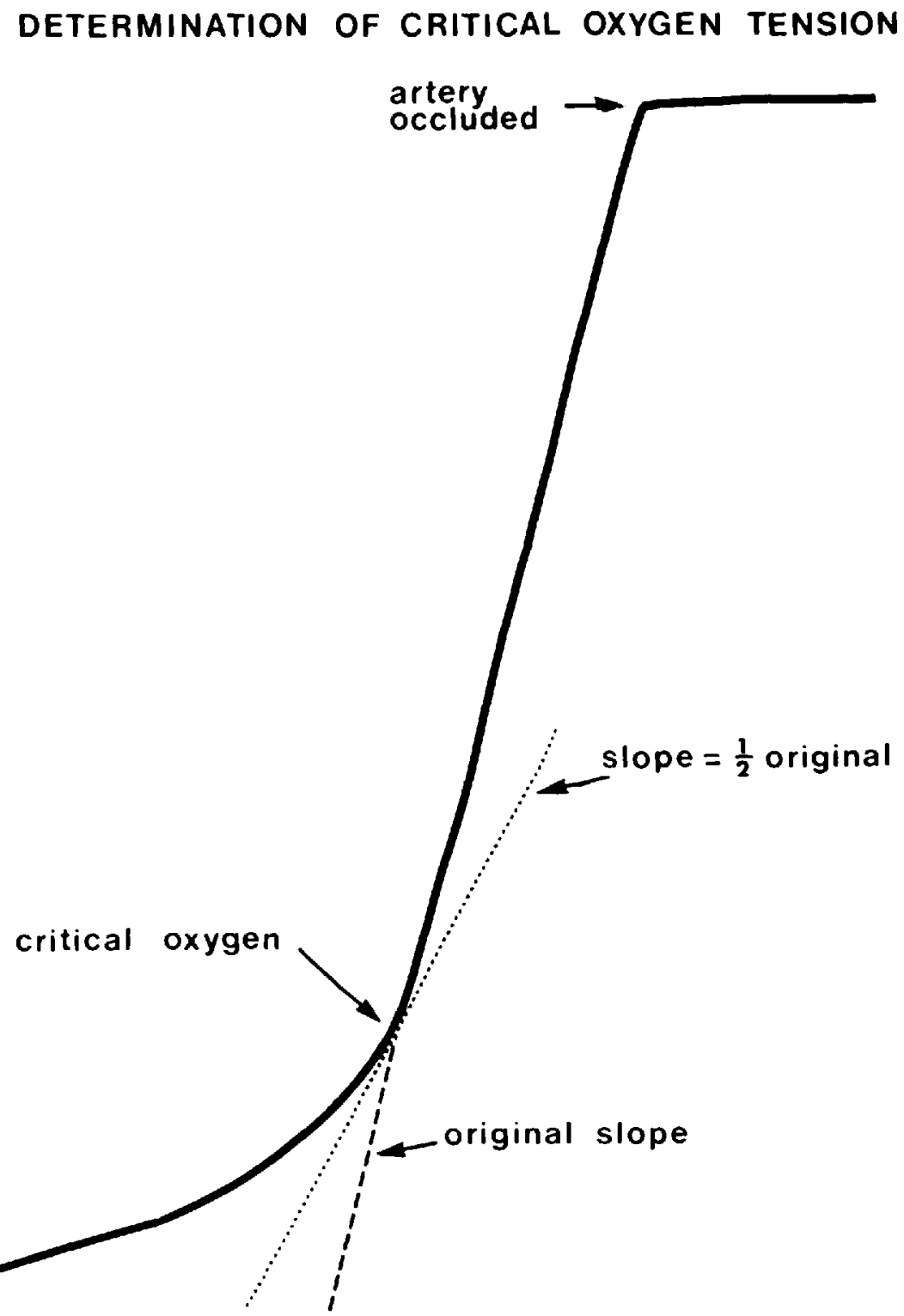

Figure 2

RESULTS

The critical oxygen tension during thiopentone anaesthesia was significantly higher than that found during halothane anaesthesia.

The readings obtained are shown in Table I. Group I represents the halothane to thiopentone series, group II the thiopentone followed by halothane series.

Figure 3 shows this data as a cumulated bar graph with standard error of the mean noted. A paired T-test was done on each group. The difference was found to be significant at $\mathrm{P}<0.001$ for groups I and II independently. 
TABLE I

Cortical Oxvgen Tensions: Groups I and II

\begin{tabular}{|c|c|c|c|c|c|}
\hline \multicolumn{3}{|c|}{$\begin{array}{c}\text { Group I } \\
\text { Critical } \mathrm{O}_{2} \mathrm{~mm} \mathrm{Hg}\end{array}$} & \multicolumn{3}{|c|}{$\begin{array}{c}\text { Group II } \\
\text { Critical } \mathrm{O}_{2} \mathrm{~mm} \mathrm{Hg}\end{array}$} \\
\hline Rabbit no. & Halothane & Thiopentone & Rabbit no. & Thiopentone & Halothane \\
\hline 1 & $\begin{array}{l}15 \\
15 \\
15\end{array}$ & $\begin{array}{l}31 \\
31 \\
31\end{array}$ & 6 & $\begin{array}{l}23 \\
27 \\
21\end{array}$ & $\begin{array}{l}14 \\
15 \\
19\end{array}$ \\
\hline 2 & $\begin{array}{l}14 \\
11 \\
19\end{array}$ & $\begin{array}{l}19 \\
19 \\
21\end{array}$ & 7 & $\begin{array}{l}27 \\
25 \\
27\end{array}$ & $\begin{array}{l}14 \\
12 \\
13\end{array}$ \\
\hline 3 & $\begin{array}{l}17 \\
17 \\
17\end{array}$ & $\begin{array}{l}26 \\
25 \\
26\end{array}$ & 8 & $\begin{array}{l}29 \\
30 \\
28\end{array}$ & $\begin{array}{l}23 \\
22 \\
23\end{array}$ \\
\hline 4 & $\begin{array}{l}13 \\
16 \\
15\end{array}$ & $\begin{array}{l}38 \\
35 \\
38\end{array}$ & 9 & $\begin{array}{l}23 \\
21 \\
23\end{array}$ & $\begin{array}{l}18 \\
17 \\
18\end{array}$ \\
\hline 5 & $\begin{array}{l}15 \\
23 \\
19\end{array}$ & $\begin{array}{l}27 \\
31 \\
31\end{array}$ & 10 & $\begin{array}{l}15 \\
15 \\
15\end{array}$ & $\begin{array}{l}12 \\
11 \\
14\end{array}$ \\
\hline $\begin{array}{l}\text { Mean } \\
\text { S.D. }\end{array}$ & $\begin{array}{r}16.1 \\
2.8 \\
\pm 0.7\end{array}$ & $\begin{array}{r}28.6 \\
6.1 \\
\pm 1.6\end{array}$ & $\begin{array}{l}\text { Mean } \\
\text { S.D. } \\
\text { S.E. }\end{array}$ & $\begin{array}{r}23.3 \\
5.1 \\
\pm i .3\end{array}$ & $\begin{array}{r}16.3 \\
4.0 \\
\pm 1.1\end{array}$ \\
\hline
\end{tabular}

\section{II halothane \\ 0
0
0 thiopentone}
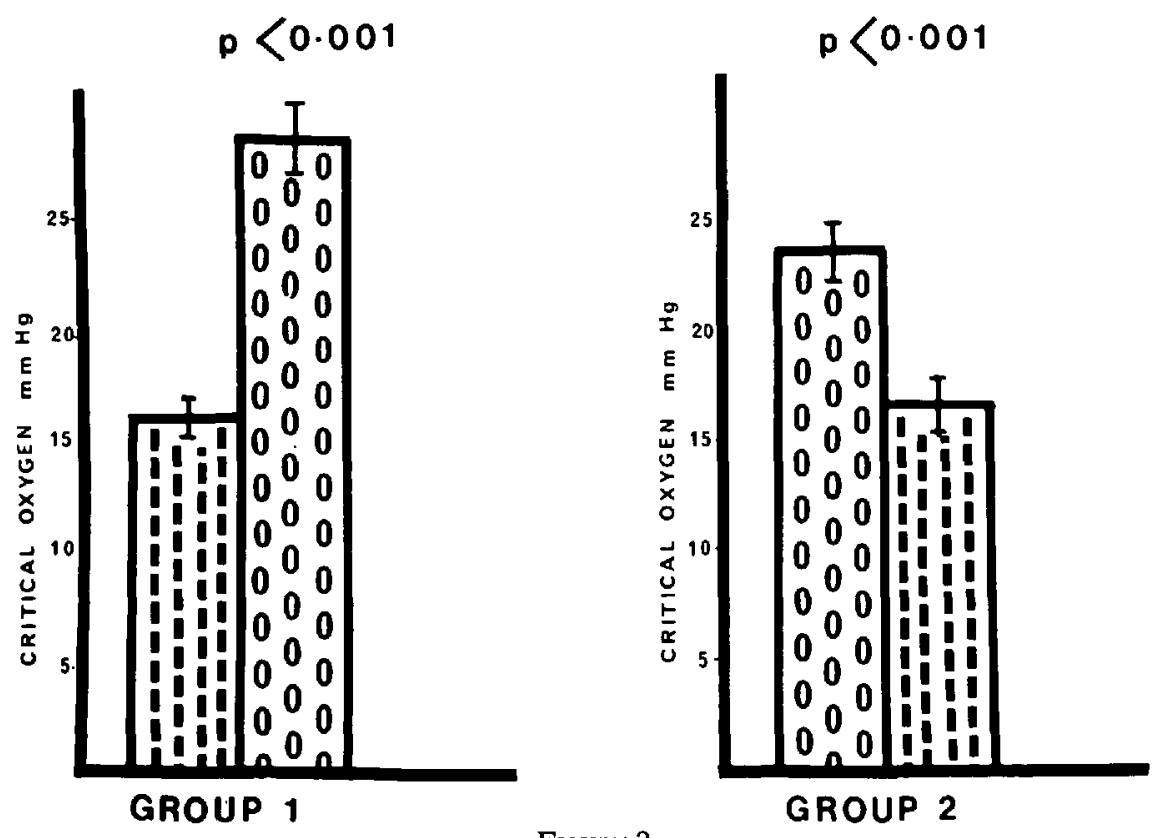

Figure 3 


\section{Discussion}

The critical oxygen tension is that tension at which oxygen consumption decreases abruptly. ${ }^{10,21}$ Fluorescent spectrometry has shown that the critical oxygen tension approximates the oxygen tension at which the oxidation/reduction ratio of the respiratory enzymes change. ${ }^{12}$ However, the critical oxygen tension better reflects the point at which the respiratory enzyme function is first compromised, since reduction can occur in the overabundance of cytochrome oxidase which exists in mammalian tissue, before oxygen consumption decreases. ${ }^{13}$

Changes in critical oxygen tension are not merely a reflection of changes in oxygen consumption. At oxygen tensions higher than the critical tension the rate of oxygen consumption is dependent on the presence of substrate and the ADP to ATP ratio. ${ }^{1+}$ It has been shown that a five-fold change in oxygen consumption may occur with only a minor change in the critical oxygen tension. ${ }^{15}$ Thus, although both barbiturates and halothane affect overall oxygen consumption, this is not the main effect on critical oxygen tension.

The critical oxygen tension as measured by surface oxygen electrode measures one point on the oxygen gradient, not the absolute tension at the respiratory enzymes. However, relative changes in the gradient are reflections of changes in oxygen tension at the mitochondria. The use of a membrane covered surface electrode allows measurement over a large area without the problems of tissue destruction of flow dependency found in larger tissue electrodes..$^{15-17}$

Previous work which shows that anaesthetics affect cellular respiratory enzyme function has been based on tissue culture. It is difficult to extrapolate from tissue culture to whole animals and difficult to compare anaesthetic concentrations to those used surgically. Many feel that clinical levels of anaesthetics affect cellular respiration primarily through changes in organ function and not by a primary effect on the enzymes. ${ }^{18,19}$ The present work, however, shows that respiratory enzyme function as reflected by critical oxygen tension is affected differently by two anaesthetics at clinical concentrations in the intact animal. There is no evidence that renal function is affected differently by these anaesthetics. Also this function is suspended with the occlusion of renal blood flow.

There has been a great deal of evidence that barbiturates protect tissue against hypoxia. ${ }^{1,2}$ It is known that anaesthetics including thiopentone and halothane result in increased ATP in areas of normal oxygen tension. ${ }^{20-21}$ After decapitation the utilization of ATP is lower with anaesthetics for a short time ${ }^{20}$ believed to be the time corresponding to tissue function. After a short period of hypoxia, however, the rate of ATP utilization is unaffected by the presence or absence of either halothane or barbiturate as contrasted to the decreased ATP utilization of hypothermia. ${ }^{19}$ We do not know, however, what happens in the area of hypoxia as opposed to that of anoxia. Oxygen consumption is decreased at a higher oxygen tension during barbiturate anaesthesia than during halothane anaesthesia. This decreased consumption may aid in preserving tissues at some point in the oxygen gradient.

\section{SUMMARY}

Critical oxygen levels measured at the rabbit renal cortex were found to be significantly higher during thiopentone anaesthesia than during halothane anaesthesia. 


\section{RÉSUMÉ}

La tension critique d'oxygène est la tension où la consommation d'oxygène diminue brusquement au niveau cellulaire. Nous avons mesuré cette tension au niveau du cortex rénal du lapin et l'avons trouvée plus élevée sous anesthésie au thiopentone que sous anesthésie à l'halothane.

\section{ACKNOWLEDGEMENTS}

The author is indebted to Dr. K.M. Leighton, and Ms. Caroline Bruce for their advice and assistance, and the support of the Departments of Pharmacology and Anaesthesia, Faculty of Medicine, University of British Columbia.

\section{REFERENCES}

1. SMITH, A., et al. Barbiturate protection in acute focal cerebral ischemia. Stroke 5: 1, pp. 1-7 (1974).

2. HoFf, J.T., SMITH, A.L., et al. Barbiturate protection from cerebral infarction in primates. Stroke 6: pp. 28-33 (Jan.-Feb., 1975).

3. Cohen, P.J. Effect of anesthetics on mitochondrial function. Anesthesiology 39: 2 (1973).

4. Quastel, J.H. \& Wheatly, A.H.M. Narcosis and oxidations of brain. Proc. Roy. Soc. (London) 113: 60-79 (1933).

5. Chance, B. \& Hollunger, G. Inhibition of electron and energy transfer on mitochondria. J. Biol. Chem. 238: 418 (1963).

6. Ernster, L., JalliNg, O., Low, H., \& Lindberg, O. Alternative pathways of mitochondria DPNH oxidation studied with amytol. Exp. Cell. Res. Supp. 3: 124 (1955).

7. Cohex, P.J., Marshall, B.E., \& LECKy, J. Effects of halothane on mitochondrial oxygen uptake: Site of action. Anesthesiology 30: 337 (1969).

8. AldRidge, W.N. \& Parker, V.H. Barbiturates and oxidative phosphorylation. Biochem. J. $76: 47(1960)$.

9. Sxodgrass, P. \& Pras, M.M. The effects of halothane on rat liver mitochondria. Biochemistry 5: $1140(1966)$.

10. Nahiwald, M. \& Cones, P.J. Anesthetics and mitochondrial respiration. In Metabolic Aspects of Anesthesia, Clinical Anesthesia, II. F.A. Davis and Co., Philadelphia, p. 1 (1975).

11. Lubbers, D.W. \& Kessler, M. Oxygen supply and rate of tissue respiration. In Oxygen Transport in Blood and Tissue, Georg Thieme Verlag, Stuttgart, p. 90 (1968).

12. Jöвsis, F.F. In Fenn, W.O. \& Rahn, H., eds., Handbook of Physiology. Section 3: Respiration. Vol. I, pp. 97-98. Washington: American Physiological Society, 1964.

13. Cones, P.T. The metabolic function of oxygen and biochemical lesions of hypoxia. Anesthesiology $37: 2$ (1972).

14. Chance, B. Cellular oxygen requirements. Fed. Proc. 16: 671-680 (1957).

15. Lubbers, D.W. The meaning of tissue oxygen distribution curves and its measurement by means of platinum electrodes. In Progress in Respiratory Research, Vol. 3: Oxygen Pressure Recording in Gases, Fluids and Tissues, S. Karger, New York (1969).

16. Lubbers, D.W. Methods of measuring oxygen tension of blood and organ surfaces. In Payne, J.P. and Hill, D.W. (eds.), Oxygen Measurements in Blood and Tissue and Their Significance, Little-Brown Co., Boston (1966).

17. Deetjen, P. Nomal and critical oxygen supply of the kidney. In Oxygen Transport in Blood and Tissue. Georg Thieme Verlag, Stuttgart (1968).

18. Mitchenfelder, J.D., Van Dyke, R.A., \& Theye, R.A. The effect of anesthetic agents and techniques on canine cerebral ATP and lactate levels. Anesthesiology 33: 315-321 (1970).

19. Mitchenfelder, J.D. \& Theye, R.A. The effects of anesthesia and hypothermia on canine cerebral ATP and lactate during anoxia produced by decapitation. Anesthesiology 33 : 430-439 (1970).

20. Folberghová, J, Lowry, O.H., \& Passonneau, J. Changes in metabolites of the energy levels in individual layers of mouse cerebral cortex and subadjacent white matter during ischemia and anaesthesia. J. Neurochem. 17: 1155-1162 (1970).

21. Brunner, E.A. \& Passonneau, J. The effect of inhalational anesthetic agents on brain metabolite levels. In Fink, B.R. (ed.), Cellular Biology and Toxicity of Anesthetics, Baltimore, Williams and Wilkins, pp. 39-47 (1972). 